\title{
A case of Klippel-Feil syndrome associated with butterfly vertebrae and hemivertebrae
}

\author{
*Imalke Kankananarachchi ${ }^{1}$, Charith Rathuwithana ${ }^{2}$, Hasini Wackwella ${ }^{2}$ L P Kolambage ${ }^{3}$ U K \\ Jayantha $^{1}$
}

Sri Lanka Journal of Child Health, 2018; 48(2): 183-185

DOI: http://dx.doi.org/10.4038/sljch.v48i2.8721

(Key words: Klippel Feil syndrome, Sprengel deformity, child, Sri Lanka)

\section{Introduction}

Klippel-Feil syndrome (KFS) is a bone disorder characterized by congenital fusion of more than two cervical vertebrae ${ }^{1}$. The prevalence of KFS is
1:40,000 to 1: 42,000 and it is more common among females ${ }^{2}$. We report a 15 month old girl with an isolated Klippel-Feil syndrome who presented with torticollis since birth.

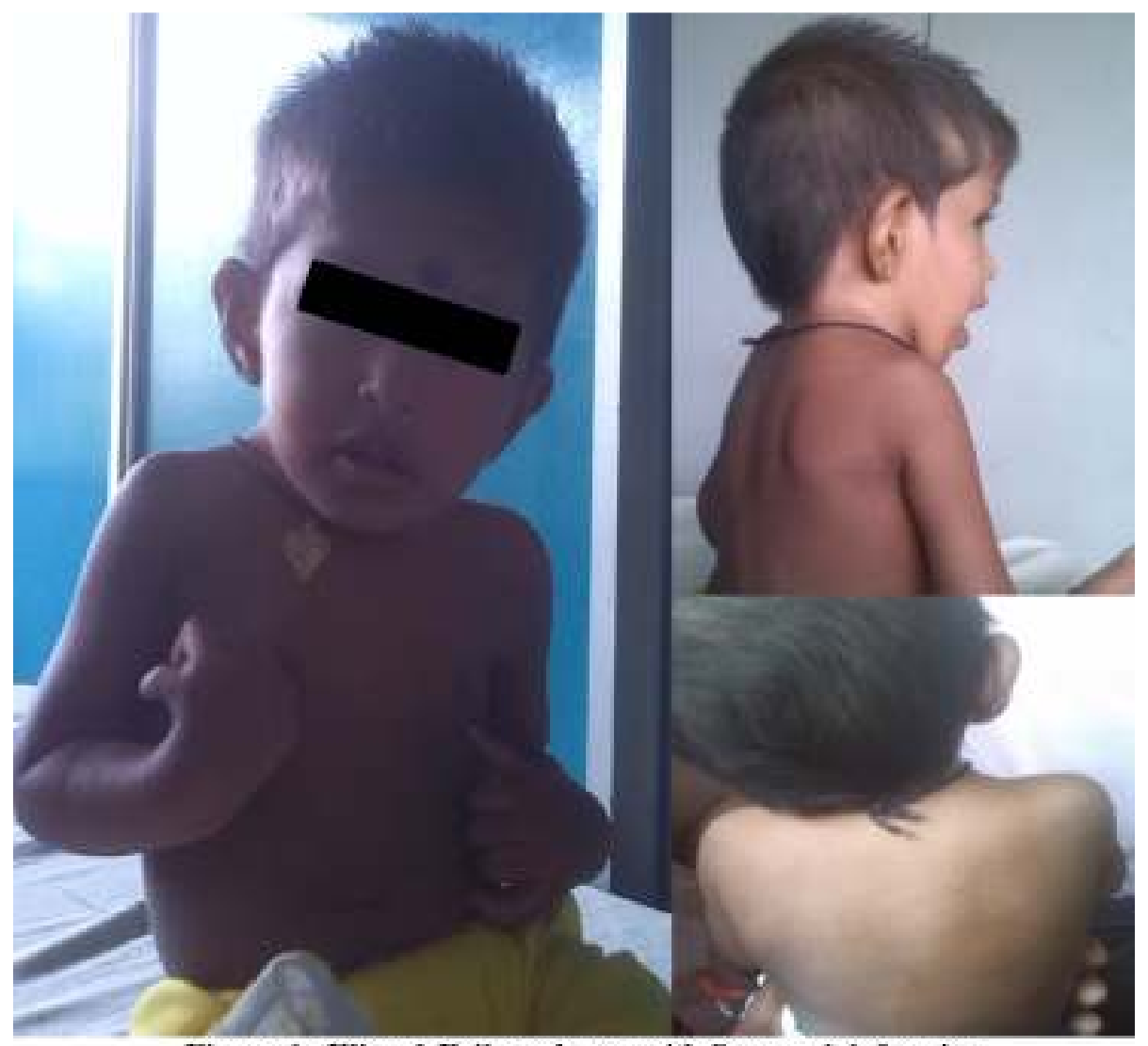

Figure 1: Klippel-Feil syndrome with Sprengel deformity

'Permission given by parents to publish photograph

${ }^{1}$ Faculty of Medicine, University of Ruhuna, Sri Lanka, ${ }^{2}$ Teaching Hospital Karapitiya, Sri Lanka, ${ }^{3}$ Department of Radiology, Teaching Hospital Karapitiya, Sri Lanka

*Correspondence: imalke462@gmail.com

(iD) https://orcid.org/0000-0002-9351-2966

(Received on 01 January 2018: Accepted after revision on 16 February 2018)

The authors declare that there are no conflicts of interest Personal funding was used for the project.

Open Access Article published under the Creative Commons Attribution CC-BY License

\section{Case Report}

A 15 month old baby girl presented with restricted neck movements since birth. She was born to nonconsanguineous parents with a birth weight of $3.1 \mathrm{~kg}$. There were no antenatal or perinatal complications and she remains otherwise healthy with age appropriate development.

Physical examination revealed a low hairline and a short, webbed neck and left sided high lying scapula (Sprengel deformity) (Figure 1). All ranges of cervical motions were restricted. She did not have any other associated craniofacial dysmorphic features. Neurological examination was normal including lower cranial nerves and upper limbs. Radiography showed a fusion of cervical as well as 
upper thoracic vertebrae and multiple butterfly vertebrae as well as hemivertebrae in cervical spine (Figure 2). Based on the above radiological features an isolated Klippel-Feil syndrome was diagnosed. Ultrasound scan of abdomen and 2D echocardiogram did not reveal any underlying renal

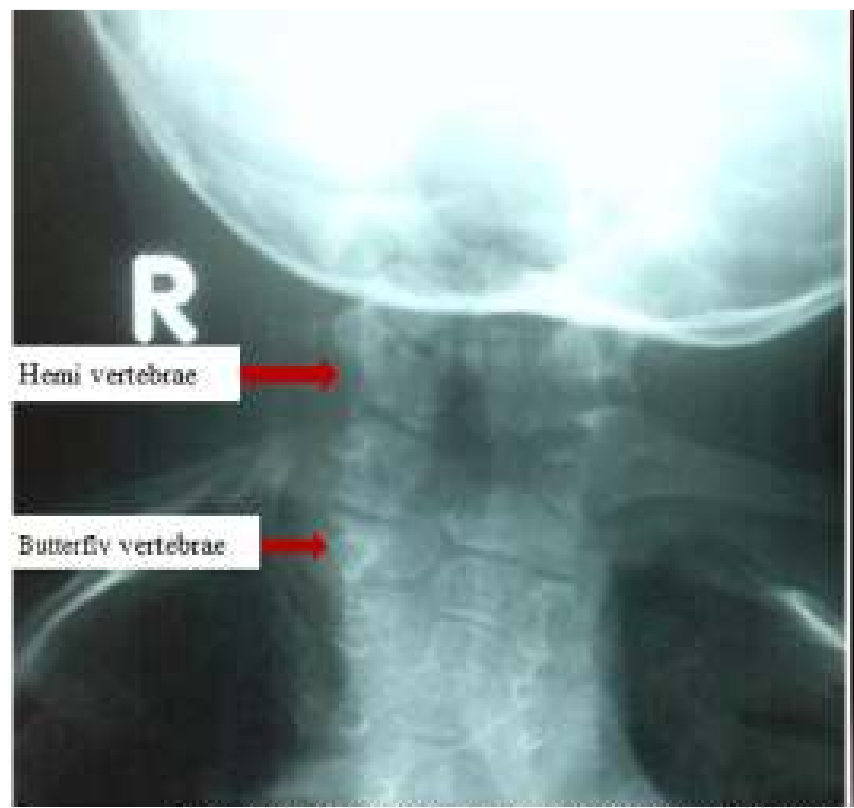

Figure 2: Cervical $x$-ray with fused vertebrae, hemi vertebrae and butterfly vertebrae

\section{Discussion}

Klippel-Feil syndrome was first described by Maurice Klippel and Andre Feil independently in $1912^{2}$. The genetic mutations involved in the KFS include GDF6, GDF3, or MEOX1, genes responsible for proper bone growth ${ }^{3}$. The hallmark of KFS is the congenital fusion of one or more cervical vertebrae resulting in severe restriction of cervical movements ${ }^{2}$. In addition, low hairline and Sprengel deformity are seen in $50 \%$ of the cases ${ }^{3}$.

Moreover, patients with KFS have other system involvements such as structural defects in genitourinary system, congenital heart diseases, cleft palate and hearing defects ${ }^{3}$. Renal agenesis, duplex system and horseshoe kidney are the underlying renal abnormalities in $\mathrm{KFS}^{3}$. However, in this child there were no associated abnormalities. The diagnosis of KFS is mainly based on the clinical findings together with characteristic radiological features ${ }^{1}$. Plain radiograph of the neck would reveal radiological abnormalities such as fused facets and spinous processes, hemivertebrae, anteroposterior narrowing of the vertebral bodies and butterfly vertebrae ${ }^{4}$. Most of these radiological findings were there in this child.

The main strategies in management of KFS include regular radiographic surveillance for hypermobile cervical vertebrae, early identification of high-risk skeletal abnormalities and physical therapy. In or cardiac abnormalities. Specific mutation analysis was not done due to limited facilities. She was followed up at the paediatric clinic with regular radiological surveillance for neurological complications.

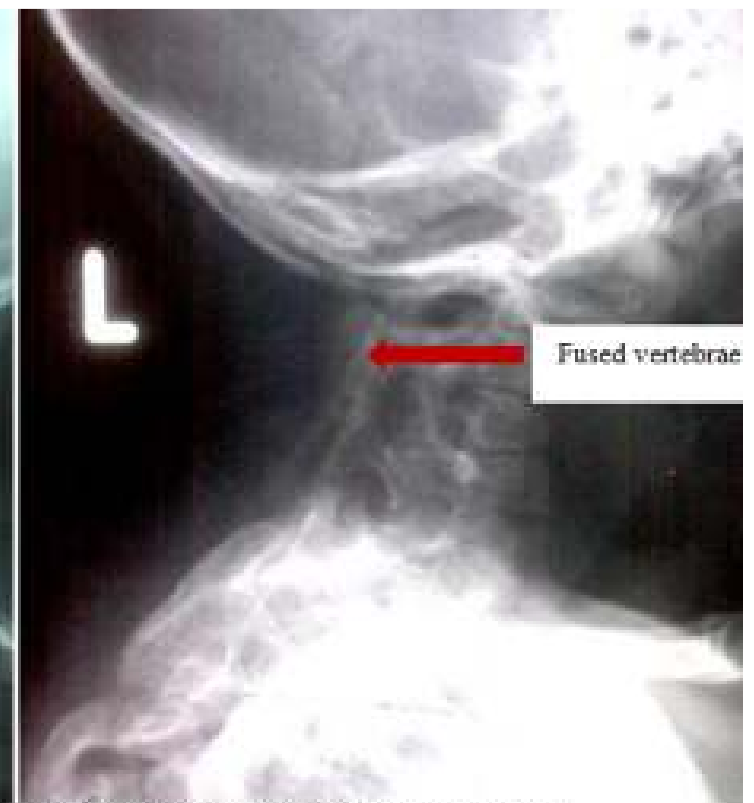

KFS, surgical treatment is indicated to relieve cranio-cervical instability and spinal cord constriction, and to correct scoliosis ${ }^{5}$. Majority of children with KFS carry a good prognosis provided the diagnosis is made early and measures are taken to prevent cervical spine damage ${ }^{6}$.

\section{References}

1. Naikmasur VG, Sattur AP, Kirty RN, et al. Type III Klippel-Feil syndrome: case report and review of associated craniofacial anomalies. Odontology 2011; 99: 197-202.

https://doi.org/10.1007/s10266-011-00047

PMid: 21597923

2. Thomsen MN, Schneider U, Weber M, Johannisson R, Niethard FU. Scoliosis and congenital anomalies associated with Klippel-Feil syndrome types I-III. Spine 1997; 22: 396-401.

https://doi.org/10.1097/000076321997021 50-00008

PMid: 9055366

3. Mohamed JY, Faqeih E, Alsiddiky A, Alshammari MJ, Ibrahim NA, Alkuraya FS. Mutations in MEOX1, encoding mesenchyme homeobox 1, cause Klippel- 
Feil anomaly. American Journal of Human Genetics 2013; 92(1):157-61.

https://doi.org/10.1016/j.ajhg.2012.11.016

PMid: 23290072 PMCid: PMC3542464

4. Clarke RA, Catalan G, Diwan AD, Kearsley JH. (). Heterogeneity in KlippelFeil syndrome: a new classification. Pediatric Radiology 1998; 28(12), 967-74. https://doi.org/10.1007/s002470050511 PMid: 9880643

5. Samartzis DD, Herman J, Lubicky JP, Shen FH. Classification of congenitally fused cervical patterns in Klippel-Feil patients: epidemiology and role in the development of cervical spine-related symptoms. Spine 2006; 31: E798-804. https://doi.org/10.1097/01.brs.000023922 2.36505.46

PMid: 17023841
6. Samartzis D, Lubicky JP, Herman J, Shen FH. Faces of Spine Care: From the Clinic and Imaging Suite. Klippel-Feil syndrome and associated abnormalities: the necessity for a multidisciplinary approach in patient management. Spine Journal 2007; 7(1): 135-7.

https://doi.org/10.1016/j.spinee.2006.05.0 19

PMid: 17269206 